\title{
V. \\ Some of the more important Works on Sociology which have appeared in the English Language since 1914.
}

By

Harry Elmer Barnes, Ph. D.

Professor of the History of Thought and Culture Clark University, U.S.A.

\section{Introductory.}

It has not been easy to plan out the best method of presenting a brief survey of the leading works on sociology which have appeared in the English language since 1914. If one were to attempt a full review of each important work the space would be exhausted by the time a half-dozen books had been described. Yet something more than a mere bibliography should be aimed at. Accordingly, I have decided to enumerate, with a brief running commentary, the more important works which have been produced by English-speaking peoples in the last eight years. It must be borne in mind that a process of selection is necessary, and the author cannot wholly escape from subjectivity in making this selection. Another writer might present a list which would vary to no inconsiderable degree from the one offered below ${ }^{1}$ ).

\section{Works on Sociological Method.}

It will be understood that the following brief list of books dealing with sociological method is not exhaustive. Leading works in all fields of sociology exhibit the application of one or another method of sociological analysis ${ }^{2}$ ). Probably the most important methodo-

1) A judgment as to the present status and future possibilities of sociology in the United States is to be found in the Publications of the American Sociological Society, 1920, pp. 174-202.

2) A notable bibliography of contributions to sociological method is contained in The American Journal of Sociology, September, 1921, pp. $226-31$. 
logical contribution is contained in the introduction to Volume I of the notable work of W. I. Thomas and F. Znaniecki on the Polish peasan $\mathrm{t}^{1}$ ). Here the sociological and cultural methods of analysiss are described and applied with remarkable skill and insight. The cultural method of analysis has been still further elaborated by Professor Znaniecki ${ }^{2}$ ). Interesting and iniportant is the effort of Professor L. T. Hobhouse to revive the statistical method which E. B. Tylor had suggested back in 1889 as applicable to the study of primitive society ${ }^{3}$ ). Even more significant is the elaboration of the historico-analytical method of anthropological and sociological analysis by Professor R. H. Lowie ${ }^{4}$, who describes and applies at some length the more critical methods introduced by Professor Franz Boas of Columbia University.

\section{Theoretical and Analytical Works.}

Probably the most notable theoretical works are those of Professor Thorstein Veblen, whose point of view is not widely different from that of Professor Werner Sombart. In a highly thoughtful series of books he has shown the maladjustment between the highly modern technical basis of contemporary industrial society and the semi-medieval social and moral institutions and ideals, with their orientation and motivating impulse in pecuniary profit. He would remedy the situation by eliminating the price-system substituting the engineer's goal of technical efficiency and social service ${ }^{5}$ ). A comprehensive outline of social philosophy has been developed by Professor J. S. Mackenzie ${ }^{6}$ ). Professor C. H. Cooley has rounded out his system of social philosophy by the third book in the series, on the whole the most systematic and comprehensive, if not the

1) The Polish Peasant in Europe and America, Vol. I, Chicago, 1918.

2) Cultural Reality, Chicago, 1919.

3) The Material Culture and Social Institutions of the Simpler Peoples, London, 1915.

4) Culture and Ethnology, N. Y., 1917.

5) The Instinct of Workmanship, N. Y., 1914; The Vested: Interests and the State of the Ind ustrial Arts, N. Y., 1919; The Place of Socience in Modern Civilization, N. $\dot{Y}_{., 2} 1919$; The Engineers and the Price System, 'N. Y., 1921.

6) Outlines of Social Philosophy, London, 1918. 
most brilliant, of the trio ${ }^{1}$ ). Professor Franklin H. Giddings has reprinted a number of his leading theoretical essays in a volume which may be regarded as the definitive summary to date of his revised system of sociolog $y^{2}$ ). Professor F. J. Teggart has contributed a very interesting discussion of the chief social processes and problems of social causation as they appear to a progressive historian ${ }^{3}$ ). Professor R. M. Maciver has developed the distinction made by Ferdinand Tönnies and Ludrig Stein between „,society" and „community" into a penetrating system of sociology ${ }^{4}$ ). His doctrines are applied to a system of social and political reconstruction by G. D. H. Cole, the intellectual leader of the English Guild Socialists ${ }^{5}$ ). Miss M. P. Follett has also made the concept of „community“ the basis for the most stin:ulating discussion of political reconstruction executed during this period $\left.{ }^{6}\right)$. Some recognition of this point of view is combined with the notion of the group constitution of society, drawn from Gierke, Maitland and Figgis, in the brilliantly written works of Professor H. J. Laski, who discusses the nature and lin.its of political authority ${ }^{7}$ ). There has not appeared during the period under discussion a comprehensive general system of sociology, comparable to those developed in the earlier works of Spencer, Ward, Giddings, Small andothers. A harbinger of such a system might, perhaps, be detected in the stimulating prolegomena by Professor Hobhouse $^{8}$ ). Professor A. G. Keller has rendered a great service, to social science by editing the scattered essays of the late Professor W. G. Sumner in four fine volumes ${ }^{9}$ ).

1) Social Process, N. Y., 1918.

2) Studies in the Theory of Human Society, N. Y., 192\%.

3) The Processes of History, New Haven, 1918.

4) Community: a Sociological Study, London, 1917.

$\left.{ }^{5}\right)$ Social Theor. , N. Y., 1920.

b) The New State, N. Y., 1918.

i) Studies in the Problem of Sovereignty, New Havew, 1917; Authority in the Modern State, New Haven, 1919; The Foundations of Sovereignty, N. Y.. 1921.

8) Social Evolution and Political Theory, N. Y., 1911.

9) War and Other Essays, New Haven, 1915; Earth II unger and Other Essays, New Haven, 1913; The Challenge of Far' and Other Essaye, New Haven, 1914; The Forgetten Man al! Other Fssays, New Haren, 1918. 


\section{Works on Psychological Sociology.}

Probably the most comprehensive contribution to psychological sociology in this period is Professor E. A. Ross' delinitive systematization of his social philosophy ${ }^{1}$ ). Professor Graham Wallas has made two notable additions to this literature by indicating the sociopsychological problems created by the Industrial Revolution and by proving the necessity of the improvement of our ,, nurture" rather than our "nature" through social invention ${ }^{2}$ ). Professor Willia $n$ McDougall attempted a supplement to his earlier work on social psychology, but the work proves to be a paean to nationalism, particularly to French and British nationalis $\mathrm{m}^{3}$ ). The work which has been most widely read and most influential in the field is the study of the psychological aspects and results of human gregariousness by Dr. Wilfred Trotter $\left.{ }^{4}\right)$. The sociological significance of individual psychic traits, as studied by the newer dynamic psychology, has been clearly presented in an admirable introductory work by Professor Irwin Edman'5). Professor C. A. Ellwood has revised and simplified his earlier systematic work on psychological sociolog $y^{6}$ ). Professor J. M. Williams has produced the prolegonena to what promises to be the most ambitious and comprehensive series of works undertaken in the field of psychological sociology?. Professor E. R. Bogardus has outlined an interesting prospectus of the field of social psycholog $\left.y^{8}\right)$. A pioneer attempt to introduce the sociopsychological technique into an analysis of economic phenomena was made by the late Professor Carlton Parker ${ }^{9}$ ). This has been regarded by many as the true initiation of the real psychological method in economics. His work has been carried still further by

1) Principles of Sociology, N. Y., 1920.

2) The Great Society, N. Y., 1914; Our Social Heritage, New Haven, 1921.

3) The Group Mind, N. Y., 1920.

4) Instincts of the Herd in Peace and War, N. Y., 1919.

5) Ifuman Traits and their Social Significance, Boston, 1920.

-) Introduction to Social Psychology, N. Y., 1917.

7) The Foundations of Social Science, N. Y., 1920 (First of a series of five Volumés).

8) The Essentials of Social Psychology, Los Angeles, 1918.

9) The Casual Laborer and Other Essays, N. Y., 1920. 
his disciple, Professor Ordway Tead $\mathrm{d}^{1}$ ). An interesting, if premature, attempt to apply the principles of the Freudian psychology to the interpretation of religious phenomena is to be found in the work of W. S. Swisher ${ }^{2}$ ). What is probably the most stimulating contribution yet made by a writer in the English language to the historical development of our socio-psychic traits is embodied in the recent work of Professor J. H. Robinson ${ }^{3}$ ). The mental tests administered to recruits in the United States army, together with tests of like character given in educational institutions, have forwarded the science of differential social psychology and established the reality and social significance of mental levels or strata in the population. Among the more important works of this character have been those by Professor Wm. McDougall, Dr. H. H. Goddard, and Dr. J. B. Miner $\left.{ }^{4}\right)$. The progress of investigation along this line has, obviously, challenged seriously some of the chief assumptions of democracy, particularly the theory of the equality and perfectibility of all the citizens. It would seem to bring forward quantitative proof of the validity of Aristotle's old dictum that some are born to rule and others to serve. The psychological problems of social reconstruction have been examined by Professor G. T. Patrick ${ }^{5}$ ).

\section{Works on Biological Sociology.}

Unquestionably the most important work on biological sociology which has appeared during this period is that in which Professor S. J. Holmes attempts to evaluate the significance of modern biological knowledge for the physical and social problems of modern society ${ }^{6}$ ). Professor A. G. Keller has made a significant effort to apply the formulae of Darwinian evolution to social evolution and social problems; yet recognizing many of the limitations involve $d^{7}$ ).

1) Instincts in Industry, Bostan, 1918.

2) Religion and the New Psychology, Boston, 1920.

3) Mind in the Making, N. Y., 1921.

4) W. McDougall, Is America Safe for Democracy?, N. Y., 1921 ; H. H. Goddard, Human Efficiency and Levels of Intelligence, Princeton, 1919; J. B. Miner, Deficiency and Delinquency, Baltimore, 1918.

5) The Psychology of Social Reconstruction, N. Y., 1920.

o) The Trend of the Race, N. Y., 1921.

7) Societal Fvolution, N. Y., 1915. 
A less critical and less successful attempt to accoinplish a sin.ilar achievement has been made by Prof essor H. W. (onn ${ }^{1}$ ). A compreinensive work, dealing with geographical and economic factors as well as the biological, has been produced by Professor Carl Kelsey ${ }^{2}$ ). The scope of his work is not far different from that of the better known works of Otto Ammon. Professor W. S. Thompson has reexamined the Malthusian doctrine in the light of the evidence which has accumulated in the century since the doctrine was pronulgated, and concludes that on all essential points the history of the last century has vindicated the conclusions of Malthus $\left.{ }^{3}\right)$. Professor M. M. Knight has presented a rather convincing criticism of Lester J. Ward's famous doctrine of ,gynaecocracy" or carly female ascendency in the race $\left.{ }^{4}\right)$. An extreme and rather anachronistic reappearance of the racial interpretation of history and social evolution is evident in the work of Dr. Madison Grant ${ }^{5}$ ), the premises of which were demolished a decade before by Professor Franz Boas in his Mind of Prinitive Man. The science of eugenics has been treated during this period in the works of Professors Conklin, Castle, Bateson, Guyer, Newman, Walter and Papenoe and Johnson ${ }^{6}$ ). Professor Conklin, in particular, has shown the sociological implications of eugenics ${ }^{7}$ ). Mrs. M. H. Sanger has presented the authoritative defenseof birth-control, a subject much more difficult to discuss sanely in America than in Europe ${ }^{8}$ ).

1) Social Heredity and Social Evolution, N. Y., 1915.

2) The Physical Basis of Society., N. Y., 1916; seo also G. H. Parker, Biology and Social-Protleme, Boston, 1914.

3) Population: a Study in Malthusianism, N. Y., 1915. Peters).

1) Taboo and Genetios,. N. Y., 1920 (With Blanchard and

$\left.{ }^{5}\right)$ The Passing of the Great Race, N. Y., 1916; sce also L. Stoddard, The Rising Lide of Color, N. Y., 1919.

6) W. Bateson, Problems of Genetics, New Haven, 1913; M. J. Guyer, Being Well-Born, Indianapolis, 1916; H. H. Nc wmen, Readings in Evolution, Genetics and Eugenics, Chigaco; 1921; H. E. Walter, Genetics, N. Y., 1913; E. G. Conklin, Heredity and Environment in the Development of Man. Princeton, 1915; Castle, W. E., Genetics and Eugenics, Cambridge, 1916:

7) The Direction of Human Evolution, N. Y.; 1920.

$\left.{ }^{8}\right)$ The Case for Birth Control, N. Y:, 1917 . 


\section{Works on Historical Sociology.}

In the field of historical sociology there has been some significant activity in the last decade. Sir J. G. Frazer has completed his great collection or religion tradition and belief ${ }^{1}$ ) and has also. attempted an anthropological analysis of the Old Testament ${ }^{2}$ ). Frazer's theoretical powers and reasoning capacity have, however, been. sharply questioned by critical scholars ${ }^{3}$ ). W. H. R. Rivers has risked. a defense of the method and conclusions of Lewis H. Morgan $n^{4}$ ), and. has contributed a monumental work on the social and cultural evolution of the Melanesians ${ }^{5}$ ). Professor H. F. Osborn has compiled an impressive and remarkably illustrated work on the early history of man and his cultural achivements ${ }^{6}$ ). Professor Arthur Keith has. executed the definitive treatment in English of the anatomical. development of man as illustrated by the early skeletal remains ${ }^{7}$ ). Professor W. Goodsell has presented a general history of the family ${ }^{8}$ ), while Professor A. W. Calhoun has produced a monumental history of the family in America ${ }^{9}$ ). Professor Hutton Webster has brought. together a remarkable compilation of material dealing with the history of tabooed and holy days $\left.{ }^{10}\right)$. Notable contributions to the history of law have been made by Professors P. Vinogradoff ${ }^{11}$ ), and Wigmore and Kocourek ${ }^{12}$ ). Professor L. T. Hobhouse has.

1) The Golden Bough, 12 Volumes, 1900-1915.

2) Folklore in the Old Testament, 3 . Volumes, N. Y., 1920.

3) Eg. R. H. Lowie, in Free man, March 30, 1921, p. 67.

4) Kinship and Social Organization, London, 1914. 1914.

5) History of Melanesiau Society, 2 Volumes, Cambridge,

6) Nen of the Old Stone Age, N.Y., 1915.

7) The Antiquity of Man, N.Y., 1915; see also Albert Church-' ward, Origin and Evolution of the Human Race, London, 1921.

8) The History of a Family as a Social and Educational Institution, N. Y., 1915.

${ }^{9}$ Social History of the American Family, 3 Volumes, Cleveland, 1917-19.

10) H. Webster, Rest Days, N. Y.; 1916.

11) Outlines of Historical Jurisprudence, Oxford, 1920.

12) Evolution of Law Series: Sources of Ancient and Pri mitive Law, Boston, 1915; Primitive and Ancient Legal Institutions, Boston, 1915; Formative Influences on Legal 
brought out a new and improved edition of his notable work on moral and social evolution $\mathrm{n}^{\mathbf{1}}$ ). Prof essor F. S. Chapin has printed a synthesis of social evolution in convenient textbook for $\mathrm{m}^{2}$ ). Mr. Edward Jenk has brought out an important book on the evolution of political institutions, which is, however, work on the anthropological side ${ }^{3}$ ). Yet by far the most important contributions to historical sociology in the last decade have been the remarkable syntheses produced by leading members of the American school of historico-analytical anthropologists, Wissler, Lowie and Goldenweiser ${ }^{4}$ ): These works may be regarded as superseding completely the older works of the type of those by Morgan, Brinton, Tylor and Frazer ${ }^{5}$ ). The sociological contributions to history have been outlined in a systematic syllabus by Professor H. E. Barnes ${ }^{6}$ ).

\section{Works on the Geographical Factors in Society.}

Unquestionably the most interesting work done on anthropogeography during this decade has been embodied in the works of Professor Ellsworth Huntington, who has dwelt particularly upon the relation of climate and climatic cycles to civilization and social problems ${ }^{7}$ ). He has also collaborated on a systematic work on anthropogeograph $\left.y^{8}\right)$. Less striking and original but more convincing is

Development, Boston, 1918; see also Roscal Pound, The Common Law, Boston, 1921.

1) Morals in Evolution, N. Y., 1915.

2) A Historical Introduction to Social Evolution, N. Y., 1914; A Historical Introduction to Social Economy, N. Y., 1917.

3) E. Jenks, The State and the Nation, London, 1919.

4) C. Wissler, The American Indian, N.Y., 1917; R. H. Lowie, Primitive Society, N.Y., 1920; A. A. Goldenweiser, Early Civiliza tion, N. Y., 1922; see also the excellent collection of Sources on early society in Kroeber and Waterman, Source.Book in Anthropology, Berk 引ley, 1921.

5) I have made a more thorough survey of the status of historical ociology in the Publications of the American Sociological Society for 1921.

6) The Social History of the Western World, N. Y., 1921.

7) Civilization and Climate, New Haven, 1915; World Power and Evolution, Now Haven, 1919.

8) The Principles of Human Geography, N. Y., 1921 (With Professor Cushing). 
the systematic work on climate and society by Professor R. D. Ward ${ }^{\mathrm{I}}$ ). Mr. H. J. Mackinder has combined geography and diplomacy in a work stressing the importance of the pivotal area about the Black and Caspian Seas, and contending that Germany must be shut off from this areas by a cordon of free states ${ }^{2}$ ). The relation between geography and social evolution has been clearly described by Professors J. Fairgrieve ${ }^{3}$ ) and A. J. Herbertson ${ }^{4}$ ). The most notable contribution to the relation of geography to history has been made by $\mathrm{Mr}$. Andrew Cowan ${ }^{5}$ ). The regional geography and sociology of Frédéric Le Play has been elaborated in English by Professor Patrick Geddes as the basis for far-reaching schemes of social and governmental reorganization ${ }^{6}$ ). One should also mention the fact the doctrines of Ratzel, Kirchhoff, Brunhes and Demolins are now available in English through paraphrases and translations?).

\section{Works on Statistical Sociology.}

The theory and methods of the statistical approach to social phenomena have been advenced by the works of Professors W. B. Bailey $^{8}$ ). A. L. Bowley ${ }^{9}$ ), W. C. Brinton ${ }^{10}$ ), G. R. Davies ${ }^{11}$ ), W. I. King ${ }^{12}$ ) and $H$. Secrist ${ }^{13}$ ). Dr. John Koren has edited a composite

1) Climate, Considered Especially in Its Relation to Man, N. Y., 1917.

2) Democratic Ideals and Reality, N. Y., 1919.

3) Geography and World Power, London, 1915.

4) Man and His Work, London, 1917.

5) Master Clues in World History, London, 1914.

6) Cities in Evolution, London, 1915; The Coming Polity, London, 1919 (With V. V. Branford).

7) E. C. Semple, Influences of Geographic Environment, N. Y., 1911 (English adaptation of Ratzel's Anthropogeographie); A. Kirchhoff, Man and Earth, N. Y., 1914; J. Brunhes, Human Geography, Chicago, 1921; E. Dernolins, How the Route Creates the Social Type, London, 1921-22.

8) Statistics, Chicago, 1917.

9) The Nature and Purpose of the Measurement of Social Phenomena, London, 1915.

10) Graphic Methods for Presenling Facts, N.Y. 1914.

11) Social Environment, Chicago, 1917.

12) Elements of Statistical Method, N. Y., 1916.

13) Introduction to Statistical Methods, N. Y., 1917. 
work on the history of statistic ${ }^{1}$ ). Professor G. H. Knibls has made a most significant contribution to the application of the statistical method to population questions ${ }^{2}$ ). Perhaps the most important advances in statistical applications have been in the field of the economic factors in society. Professor W. C. Mitchell has contributed a monumental historical and descriptive work on business cycles $\left.^{2}\right)$. This is well supplemented by a more distinctly methodological and theoretical work by Professor H. L. Moor $\mathrm{e}^{4}$ ). This last work, together with Professor Morre's work on wage ${ }^{5}$ ), are the most notable of the American developments in the mathematical method in economic analysis. Another important descriptive work is that of Professor M. T. Copeland and other Harvard economists on business statistics ${ }^{6}$ ). But much the most interesting of the examples of this type of work has been that done by Bowley and Mitchell, in their studies of the income of Great Britain and the United States. Bowley has brought forth the most telling implied criticism of communistic socialism yet produced, by showing that an equal division of the income of Great Britain would not insure a decent competence, much less, opulence for the citizens of Britain ${ }^{7}$ ). The study of income in the United States by Mitchell and his associates has been only less disconcerting to communists, though unquestionably an equal indictment of American plutocracy ${ }^{8}$ ). The rule of America by dynastic wealth has been convincingly demonstrated by Mr. H. H. Klein and R. R. Pettigrew ${ }^{9}$ ). There is no doubt about the activity of the statistical sociologists, but the work in social statistics has too frequently been defective because

1) History of Statistics, N. Y., 1917.

2) The Mathematical Theory of Population, Melbourne, 1917.

3) Business Cycles, Berkeley, 1913 .

4) Economic Cycles, N. Y., 1914.

5) The Laws of Wages, N. Y., 1911.

6) Business Statistics, Cambridge 1917.

?) The Division of the Product of Industry, Oxford, 1919; Bowley, The Change in the Distribution of National Income, Oxford, 1920.

8) Income in the Unites States, $1909-1919$, N. Y., 1822.

9) H. H. Klein, Dynastic A.merica, N. Y., 1921; R. R. Pet-tigrew, Triumphant Plotocracy, N. Y., 1922. 
of the failure of many British and most American statisticians to master the Pearson method of utilizing the coefficient of correlation.

\section{Works on Practical and Applied _Sociology.}

This field is the one in which sociological work has been most prolific for the last two decades, even though the United States is still the most dominated by laissez-faire concepts and practices in law and politics of the great states of the world. The general premises, motives, aims and province of practical sociology and the leading modern social problems are well surveyed by Professors C. A. Ellwood, E. C. Hayes, H. P. Fairchild, A. B. Wolfe, J. H. Tufts, and $H$. K. Rowe ${ }^{1}$ ). Professor T. N. Carver has discussed the province of state activity in social and economic problems, holding to asomewhat mitigated Spencerian laissez-faire point of view ${ }^{2}$ ). The opposite point of view is taken by J.. A. Hobson in what is conceded to be the most important work in the English language on welfare or social economics ${ }^{3}$ ) - the culmination of the work begun a century ago by Sismondi. The immigration problem has a practical significance in the United States far beyond what it has in any other country. Professor E. A. Ross has vigorously criticized the failure to restrict immigration ${ }^{4}$ ). Professor H. P. Fairchild, in the most systematic work on the subject, also comes to the conclusion that unrestricted immigration has been detrimental to the country ${ }^{5}$ ). Professors J. W. Jenks and W. J. Lauck have examined the immigration problem, especially in its relation to labor $\left.{ }^{6}\right)$. A rather more specialized work, inclining to estimate favorably the effects of unrestricted immigration in the United States, has been produced

1) C. A. Ellwood, The Social Problem, N.Y., 1915; E.C. Hayes, Sociology and Ethics, N.Y., 1921; H. P. Fairchild, Outlines of Applied Sociology, N. Y., 1916; A. B. Wolfe, Readings in Social Problems, Boston, 1916; J. H. Tufts, The Real Business of Liring, N. Y., 1918; H. K. Rowe, Society, Its Origin and Development, N. Y., 1916.

2) Essays on Social Justice, Cambridge, 1915.

3) Work and Wealth, N. Y., 1914.

4) The Old World in the New, N. Y., 1914.

$\left.{ }^{5}\right)$ Immigration, N. Y., 1913.

6) The Immigration Problem, N. Y.. 1917. 
by Dr. I. A. Hourwich ${ }^{1}$ ). A vast mass of information on the subject has been printed by the Immigration Commission ${ }^{2}$ ). Mr. Harold Stearne bas edited an important work in which contemporary American Society is subjected to a criticism and appraisal ${ }^{3}$ ). Dr. F. C. Howe has brought together a synthesis of the social problems of modern urban life ${ }^{4}$ ), while Professors P. L. Vogt, J. M. Gillette, and G. Phelan have worked out comprehensive surveys of rural social problems and their solution ${ }^{5}$ ). The problem of poverty, its causes, amelioration and elimination, has been considered in two comprehensive works by Professors M. Parmelee and J. L. Gillin ${ }^{6}$ ). Professor G. B. Mangold has compiled the standard treatment of the problem of the child in modern society ${ }^{7}$ ). Mr. H. Seligman has brought out a penetrating study of the serious negro problem in the United States ${ }^{8}$ ). Professor J. H. Leuba has gathered a striking body of information indicating the decline of religious orthodoxy among the educated classes in the country ${ }^{9}$ ). Dr. I. M. Rubinow has executed the most systematic work in English on social insurance ${ }^{10}$ ): An admirable introduction to the whole field of mental hygiene from the standpoint of the most modern psychiatry is to be found in the work of Dr. W. A. White ${ }^{11}$ ). The causation and social significance of defective mentality has been studied in detail by Dr. H. H. Goddard ${ }^{12}$ ). The study of the problems of crime and punishment has been actively advanced in the last decade in the works of $M$. Par-

1) Immigration and Labor, N. Y.Z 1912.

2) Report of the United States Immigration Commission, Washington, 1911.

3) Civilization in the United States, N. Y., 1922.

4) The Modern City and Its Problems, N. Y., 1915.

5) J. M. Gillette, Constructive Rural Sociology, N. Y., 1913;

P. L. Vogt, An Introduction to Rural Sociology, N. Y., 1917; J. Phelan, Readings in Rural Sociology, N. Y., 1920.

6) M. Parmelee, Poverty and Social Progress, N. Y., 1916;

J. L. Gillin, Poverty and Dependency, N. Y., 1921.

7) Problems of Child Welfare, N. Y., 1914.

8) The Negro Faces America, N. Y., 1920.

9) The Belief in God and Immortality, Boston, 1916.

10) Social Insurance, N. Y., 1913.

11) Principles of Mental Hygiene, N. Y., 1917.

12) The Kallikak Family, N. Y., 1912; Feeble-Mindedness, N. Y., 1914; The Criminal Imbecile, N. Y., 1915. 
melce, L. N. Robinson, G. Ives, P. Klein, H. E. Barnes, B. Lewis, T. M. Osborne, W. Healy and B. Glueck $\left.{ }^{1}\right)$. Mr. Osborne has been the recognized practical leader in penal reform in the last decade. The labor problem has been studied by Professor J. R. Commons, G. G. Groat, Mr. F. Tannenbaum, Budish and Soule, and many who have written on special phases of the subject $\left.{ }^{2}\right)$. An admirable bibliography of such works has been prepared by Mr. S. Ziemand ${ }^{3}$ ). The last field of applied sociology which may be mentioned here is that of educational sociology. To this field important contributions have been made by Professors G. H. Betts, W. E. Chancellor, F. R. Clow, C. L. Robbins, I. King, W. R. Smith, D. S. Snedden and 'I. Veblen ${ }^{4}$ ). Particularly significant is the work by Professor Veblen, which makes clear the relation between great wealth and university administration and instruction in America.

1) M. Parmelee, Criminology, N. Y., 1918; L. N. Robinson, Penology in the United States, Philadelphia, 1922; G. Ives, A History of Penal Methods, London, 1914; P. Klein, Prison Methods in New York State, N. Y., 1919; H. E. Barnes, History of the Penal Institutions of New Jersey, Trenton, 1918; B. Lewis, The Offender, N. Y., 1917; T. M. Osborne, Society and Its Prisons, New Haven, 1916; W. Healy, The Individual Delin. quent, Boston, 1915; B. Glueck, Forensic Psychiatry, Boston, 1916.

2) J. R. Commons, Trade Unionism and Labour Problems (Readings), Boston, 1920; J. R. Commons et al, History of Labour in the United States, 2.Volumes, N. Y., 1918; G. G. Groat, An Introduction to the Study of Organized Labour in the United States, N.Y., 1916; F. Tannenbaum, The Labour Morement, N. Y., 1921; Budish and Soule, The New Unionism in the Clothing Industry, N. Y., 1920; The last work is a study of the strongest, most progressire. and Most constructive Labour Union in the United states.

3) Modern Social Movements, N. Y., 1920.

') G. H. Betts, Social Principles of Education, N. Y., 1912; W. E. Chanceller, Educational Sociology, N. R., 1919; F. R. Clow, - Principles of Sociology with Educational Applications, N. Y., 1920; C. L. Robbins, The School as a Social Institution, Boston, 1917; I. King, Social Aspects of Education, N. Y., 1912; W. R. Smith, An Introduction to Educational Sociology, Boston, 1917; D. S. Snedden, The Sociological Determination of Objectives in Education, Philadelphia, 1921; T. Veblen, The Higher Learning in America, N. Y., 1918.

Archiv für Geschichte der Philosophie XXXIV. 3. u. 4. 


\section{Works on the History of Sociological Thought.}

Prolessor E. R. J3ogardus has just brought out the first coinprehensive treatment of the history of sociology ${ }^{1}$ ). An excellent treatment of sociology since Comte is to be found in the book by Prnlessor 1. M. Bristol ${ }^{2}$ ). Professor A. J. Todd has produced an exposition and critique of the various theories of social progress ${ }^{3}$ ). Professor W. A. Dunning has completed his three volume history of political theories in a work which constitutes an admirable introduction to the formative period of sociological doctrin $e^{4}$ ). An encyclopedic study of American political and social theory since $\mathbf{1 8 6 5}$ has recently come from the pen of Professor C. E. Merriam ${ }^{5}$ ). Professor H. E. Barnes has set forth in the American Journal of Sociology and other professional periodicals a study of the development of sociology, particularly in its relation to political theory. A timely historic survey of Russian sociology has been executed by Professor J. F. Hecker ${ }^{6}$ ). A. H. Koller, has attempted a brief sketch of the development of anthropogeography ${ }^{7}$ ). Professor 0. F. Boucke has surveyed the history of economic theory since 1750 in a work which includes much valuable material on the history of sociological thought ${ }^{8}$ ). Syndicalism in France has been surveyed by L. Levine ${ }^{9}$ ), and in the United States by P. Brissenden ${ }^{10}$ ). Professor P. J. Moon has surveyed the social doctrines of catholicism, particularly in France ${ }^{11}$ ).

\section{Textbooks in Sociology.}

There have been some notable additions to the textbook literature of general sociology since 1914. A comprehensive survey of the

1) A History of Sociological Thought, Los Angeles, 1922.

2) Social Adaptation, Cambridge, 1915.

3) Theories of Social Progress, N. Y., 1918.

4) Political Theories from Rousseau to Spencer, N. R., 1920.

5) American Political Ideas, 1865-1917, N. Y., 1920.

6) Russian Sociology, N.Y., 1915.

7) The Theory of Environment, Menasha, 1918.

8) The Development of Economics, 1750-1900, N.Y., 192j.

-) Syndicalism in France, N. Y., 1914.

10) The I. W. W.: A Study in American Syndicalism, N. Y., 1919.

11) The Labor Problem and the Social Catholic Movement in France, N. Y., 1921. 
whole field of sociology appeared in the work of Professors F. W. Blackmar and J. L. Gillin ${ }^{1}$ ). A better organized and more serviceable textbook is that by Professor E. C. Hayes ${ }^{2}$ ). A well proportioned and mature work, stressing somewhat the doctrines of Lester F. Ward, is Professor J. Q. Dealey's latest work ${ }^{3}$ ). A somewhat original project in the textbook line is the recent voluminous work of Professors E. W. Burgess and R. Park, in which the subject-matter is presented in the form of a wide variety of well selected sources, chosen from many modern writers ${ }^{4}$ ).

\section{The Sociology of War and Reconstruction.}

While the War period and its emotional stresses served to lessen the objectivity of English-speaking sociologists, there have been, nevertheless, some very penetrating studies of the causes and nature of war, and of the problems of peace and reconstruction, which aim to discover the basic scientific causes for the conflict and the real solution of the problems of reconstruction, rather than to attempt to prove the full German responsibility for the War or to accept the doctrine of a German scapegoat as an adequate program for afterwar reconstruction. Professors J. H. Rose and R. Muir have sketched the history of modern nationalism, which has had so powerful an influence in generating the belligerent psychology which did so much to bring on the World War ${ }^{5}$ ). Professor W. B. Pillsbury and Dr. G. E. Partridge have analyzed the psychology of nationalism and patriotism ${ }^{6}$ ). Professor J. F. Scott has described the system of patriotic education which has played a dominating part in creating the obsessed nationalism of the quarter of a century before 19147). Professor T. Veblen has clearly shown the manner in which modern

1 Outlines of Sociology, N. Y., 1915.

2) Introduction to the Study of Sociology, N. Y., 1915. 1920 .

3) Sociology, Its Development and Applications, N. Y.,

4) Introduction to the Science of Society, Chicago, 1921.

5) J. H. Rose, Nationality in Modern History, N. Y., 1916; R. Muir, Nationalism and Internationalism, Boston, 1917.

6) W. B. Pillsbury, The Psychology of Nationality and Internationalism, N. Y., 1919; G. E. Partridge, The Psychology of Nations, N. Y., 1919.

7) Patriots in the Making, N. Y., 1916. 
patriotism and capitalism inevitably invite war and obstruct pacific adjustments ${ }^{1}$ ), and has indicated the historical reasons for the growth of German militarism and nationalism in the period since $1870^{2}$ ). Professor L. T. Hobhouse has executed a thoughtful study of the sociological causes of the World War and the constructive measures necessary if any permanent peace is to be secured $\left.{ }^{3}\right)$. Professor G. Stanley Hall has made a comprehensive study of the psychological basis of morale in peace and war ${ }^{4}$ ). Bertrand Russell and H. H. Powers have analyzed the psychological and economic illusions which furnish the more powerful impulses leading to $\mathrm{war}^{5}$ ). Mr. Norman Angell has contended that the World War furnished a gigantic and tragic proof of the truth of the main theses in his notable work The Great Illusion ${ }^{6}$ ). Mr. Will Irwin has warned of the terrible devastation which the ,next war" will inevitably produce, thus aiming to produce a desire to take steps to avoid its occurrence ${ }^{7}$ ). Mr. F. S. Marvin has edited a valuable work sketching the history of forces makingfor world peace ${ }^{8}$ ). Professor Stephen P. Duggan has edited the standard treatise on the League of Nations and its problems ${ }^{9}$ ).

Messrs. P. B. Noyes, J. M. Keynes, Bass and Moulton and F. Vanderlip have indicated the economic weaknesses of the Peace of Versailles and the necessity of revising it if Europe is to recover from the tragic consequences of the War and the equally disastrous peace ${ }^{10}$ ). Professor J. A. Hobson has set forth a profound analysis of

1) An Inquiry into the Nature of Peace and the Means of Its Perpetuation, N. Y., 1917.

2) Imperial Germany and the Industrial Revolution, N. Y., 1915.

3) The World in Conflict, London, 1915; Questions of War and Peace, London, 1916.

4) Morâle: the Supreme Standard of Life and Conduct, N. Y., 1920.

8) B. Russell, Why Men Fight, N. Y., 1917; H. H. Powers, Things Men Fight For, N. R., 1916.

6) The Fruits of Victory, N. Y., 1921.

7) The Next War, N. Y., 1921.

8) The Evolution of World Peace, Oxford, 1921.

9) The League of Nations, Boston, 1919.

10) P. B. Noyes, While Europe Waits for Peace, N. Y., 1921; J.M. Keynes, The Economic Consequences of the Peace, N.Y., 1920; A Revision of the Treaty, N. Y., 1922; Bass and Moulton, 
the basic causes of the World War and the most important problems to be solved during the period of social and international reconstruction $^{\mathbf{1}}$ ). Professor Harry Ward has offered some suggestions as to the desirable social organization for the post-war world and possible means of bringing about its realization ${ }^{2}$ ). Professor Graham Wallas has insisted that all of these plans for perpetual peace and social reconstruction will come to naught unless we improve the technique of social invention ${ }^{3}$ ). Professor R. H. Tawney, in what is probably the mòst important critique of modern capitalistic society contributed during the last generation, has shown that what is needed for peace at home and abroad is a revision of the economic and social orientation of modern society, with the goal and processes which dominate it $\mathbf{t}^{\mathbf{4}}$.

The Balance Sheet of Europe, N.Y., 1921; F. Vanderlip, What's Next in Europe, N. Y., 1921.

1) Problems of a New World, N.Y., 1921.

2) The New Social Order, N. Y., 1919.

$\left.{ }^{3}\right)$ Our Social Heritage, New Haven, 1921.

4) The Acquisitive Society, N. Y., 1920. 